\title{
A Study of factors affecting consumer's online shopping behavior and their impact on Behavioral Intention
}

\author{
Effulgence \\ Vol. 17, No. 2 (Special Issue) \\ July - December 2019 \\ Rukmini Devi Institute of Advanced Studies \\ E-mail : effulgence@rdias.ac.in, Website : www.rdias.ac.in \\ http://effulgence.rdias.ac.in/user/default.aspx \\ https://dx.doi.org/10.33601/effulgence.rdias/v17/iSpl2/2019/101-113
}

\author{
Mr. Anurag pandey ${ }^{1} \bowtie$ \\ Dr. Jitesh S. Parmar ${ }^{2}$
}

\begin{abstract}
Purpose - To find out the factors affecting consumer's online shopping behavior and their impact on Behavioral Intention.

Design/methodology/approach - A Cross-sectional descriptive study using snowball sampling for selecting the samples from online shopping users of 11 district of Central U.P. The schedule and Web based structured questionnaire have been used for collecting the data. The factor analysis is performed for identifying the factors, the multiple regression analysis is used for creating a regression line.
\end{abstract}

Findings - The study results recommend that consumers' online shopping behavior is being affected by several factors like social influence, self-efficacy, perceived credibility, performance expectancy, effort expectancy, website design, social media, and delivery of goods.

Research limitations/implications - The study results can be generalized to the online shopping users of selected district of central U.P. only. In future studies, more statistical techniques might be applied for improving the conclusiveness of the findings reported in the study.

Practical Implications - The researcher can use the findings of the study in future studies. The findings can be implemented by online retailers in decision making while making their marketing program.

Originality/value - The paper is based on original work, the questionnaire has been found reliable after checking the Cronbach's Alpha value. The KMO values supports the adequacy of sample size and found significant for applying Exploratory Factor Analysis.

Keywords: Consumer behaviour, online shopping, Internet shopping, Electronic commerce, multiple regression, EFA, consumer satisfaction.

1. UKA Tarsadia University, Surat, Assistant Professor, PSIT College of Engineering, Bhaunti, Kanpur (U.P.), anurag12488@gmail.com

2. Associate Professor, Shrimad Rajchandra Institute of Management and Computer Application, Gopal Vidyanagar, Bardoli, Mahuva Road, Dist. Surat, Gujarat, jiteshsp@gmail.com 


\section{INTRODUCTION}

$\mathrm{T}$ he online shopping has changed the trends of retailing in India. The Indian online retailing is the fastest growing market and it is expected to reach to US\$ 120 billion by 2020 (IBEF, 2019)As online shopping is emerging, it motivates a researcher to identify the factors which motivates a consumer to buy a product online, and what are the factors which discouraged a consumer not to buy online. The studies on online shopping has been conducting for last 25 years. And in those researches many factors; social influence, self-efficacy, perceived credibility, performance expectancy, effort expectancy, website design, social media, and delivery of goods etc. have been found which affects consumer's online shopping behavior. But whatever the factors have been found, there effect on consumer's buying behavior changes with the changes of time. In this research study the attempt is made to know impact of factors on consumer's buying intention in Central U.P. The central U.P. has been covering so many 13 district having population of 39.84 crore (census, 2011) which are urban and rural based. Uttar Pradesh is the state which contributes ₹15.80 lakh crore in total GDP of India.

Earlier the online shopping was used by the consumers belonging to the metro city and urban city. In the current scenario the online shopping has been used by consumers belonging to the rural based cities. The consumers do not feel risky while purchasing the product online. The online shopping users have been increasing in India. The internet and smart phone users have been increasing in India and it is expected to reach to 829 million internet users by 2021 in India. The various initiatives of Government of India, namely skill India, Make in India, Digital India, and Startup India has been supporting the ecommerce in India.

\section{LITERATURE REVIEW}

According to (Pengnate \& Sarathy, 2017), customer trust on online shopping is highly influenced by ease of use and visual appeal of the website.

According to (Hausman \& Siekpe, 2009), using humors, 3D visuals, appealing graphics attract, motivate and retain the consumers to purchase from the website. The website should be more informative, avoid irritation so that consumers can understand the website layout and navigate the required products easily.

According (Bai, Law, \& Wen, 2008), customer satisfaction is directly and positively affected by the website quality and customer satisfaction directly and positively impact purchase intention of customer.

According to (Singh, Fassorr, Chao, \& Hoffmann, 2006), consumer's attitude towards international websites is positively affected by perceived usefulness, perceived ease of use, and purchase intention of the consumers has been directly impacted by perceived usefulness of the website.

\section{H0a: Website Design is not having significant impact on consumer's online shopping Behavioral Intention.}

According to (Venkatesh, Thong, \& Xu, March 2012) consumer's habit of using internet positively affect the behavioural intention of the consumer.

According to (Hernandez, Jimenez, \& Martin, 2009), habits are an important explanatory variable in models related to Information Technology.

H0b: Habit is not having significant impact on consumer's online shopping Behavioral Intention.

According to (Tarhini, Alalwan, Al-Qirim,

Algharabat, \& Masa'deh,, 2018), behavioral intention is positively affected by service quality, performance expectancy, and compatibility.

According to (Gupta \& Arora, 2017), behavioral 
intention to adopt mobile shopping is influenced by variety of product, convenience, exclusive offer, and price saving.

According to (Venkatesh, Thong, \& Xu, March 2012) performance expectancy is having positive impact on behavioral intention.

According to (Kim \& Lim, 2010), Entertainment, information quality, convenience, reliability, and speed is having a positive impact on consumer.

According to (Hernandez, Jimenez, \& Martin, 2009), Perceived usefulness is having a positive impact on present purchasing behavior and attitude towards epurchasing.

H0c: Performance Expectancy is not having significant impact on consumer's online shopping Behavioral Intention.

According to (Park \& Cho, 2012), Commitment to a social network online community is having a positive relationship with information finding behavior at the community.

According to (Wang, Yu, \& Wei, 2012), purchasing decisions are directly or indirectly affected by the Online consumer socialization through peer communication. Product attitude is affected by Peer communication, in turn purchase intentions are enhanced by it.

According to (Pookulangara \& Koesler, 2011), perceived usefulness of social network affect the intention of using social network which further affect the online purchase intention.

According to Zhu F., Zhang X., (2010), less popular games are more influenced by online reviews, the informational role of reviews becomes more important for new marketers.

H0d: Social Media is not having significant impact on consumer's online shopping Behavioral

\section{Intention.}

According to (Tarhini, Alalwan, Al-Qirim, Algharabat, \& Masa'deh,, 2018), effort expectancy and social influence does not have influence on behavioral intention.

Acording to (Changchit, Cutshall, Lonkani, Pholwan, \& Pongwiritthon, 2018), perceived ease of use, past experience, and perceived security is having an influence on attitude of shopping online.

According to Azzam Al, Mahmoud Abdel Fattah (2014) perceived ease of use; perceived behavioral control, affect the consumer's onine shopping behavior.

According to (Hernandez, Jimenez, \& Martin, 2009), Experienced consumer's behavior is explained by self-efficacy and usefulness perceived by the consumer.

H0e: Effort Expectancy is not having significant impact on consumer's online shopping Behavioral Intention.

According to (Alnsour, Ismael, Nsoor, \& Feidi, 2019) behavioral intention or adoption of online shopping is negatively affected by the product risk and payment risk.

Accoording to (Bianchi \& Andrews, 2012), perceived risk is having inverse relationship with attitude towards online shopping and it has positive impact on intention to continue purchasing online.

Sally Harridge-March, (2006), trust is having an impact on consumer's online shopping behavior.

According to ( $\mathrm{Lu}, \mathrm{Hsu}, \& \mathrm{Hsu}, 2005)$, perceived risk has impact on attitude towards use of online shopping and it directly and positively affect behavioral intention.

HOf: Perceived Credibility is not having significant impact on consumer's online shopping Behavioral 


\section{Intention.}

According to (Cao, Ajjan, \& Hong, 2018) customer satisfaction is affected by the tracking and post purchase shipping services.

According to Alsharif F., (2013), absence of delivery services influence the purchase intention of consumer while shopping online.

H0g: Delivery of Goods is not having significant impact on consumer's online shopping Behavioral Intention.

According to (Tandon, Kiran, \& Sah, 2017), behavioral intention to purchase on line is influenced by lack of touch and feel, technology ignorance factor, risk of losing personal and financial information, delivery procedures and perceived risk.

According to (Gupta \& Arora, 2017), self-efficacy, relative advantage, consumer anxiety are the variable because of that consumers do not adopt mobile shopping. Consumers have lack of confidence in using online shopping through mobile.

According to Alsharif F., (2013) computer Anxiety has direct and positive influence on Behavioral Intention.

HOh: Computer Anxiety is not having significant impact on consumer's online shopping Behavioral Intention.

According to (Hill \& Beatty, 2011)Self-efficacy is having a great influence on households decision making, households members allow adults more credibility in online shopping due to their online shopping skills.

According to (Hernandez, Jimenez, \& Martin, 2009), Self-efficacy perceived by consumers positively impact the E-purchasing.

HOi: Self-Efficacy is not having significant impact on consumer's online shopping Behavioral Intention.

According to (Izogo \& Jayawardhena, 2018) online shoppers snatch the reviews of other online shoppers as suitable platform for understanding their satisfaction level with the product.

According to (Singh, et al., 2016), customer reviews are helpful while taking purchase decision, the readability, subjectivity, entropy, polarity features of review, and average review rating of the product have a positive impact on purchase decision.

According to (Gauri, Bhatnagar, \& Rao, 2008), positive customer reviews influence repurchase intention.

According to (Hassanein \& Head, 2007), perceived usefulness, consumer attitude, trust and behavior towards online shopping is positively influenced by perceived social presence.

H0j: Social Influence is not having significant impact on consumer's online shopping Behavioral Intention.

According to (Venkatesh, Thong, \& Xu, March 2012), hedonic motivation has direct or positive influence on consumer's online shopping behavioral intention.

According to (Hill \& Beatty, 2011), hedonic and utilitarian motives for shopping online makes consumers competent shopper and increase frequency of shopping.

H0k: Hedonic Motivation is not having significant impact on consumer's online shopping Behavioral Intention.

\section{Research Methodology:}

The data was collected from the respondents those are having experience of online shopping in Central U.P. The data was collected form 545 respondents 
and out of that 40 responses were found incomplete and 505 responses were used for further analysis. Sample size greater than 500 is very good (Comrey \& Lee, 1992). Snowball and purposive sampling was used because the respondents were requested to forward the questionnaire to their friends those are having experience of online shopping. A structured questionnaire including dichotomous, multiple choice, and the questions based on 7 point likert scale were used. The likert scale has considered as interval scale, where 1 indicates strongly disagree and 7 indicates strongly agree. The descriptive statistics, reliability test based on Cronbach's Alpha value, exploratory factor analysis using Maximum likelihood method with 'promax' method of rotation and multiple regression analysis with stepwise method was the statistical measures and test, used for data analysis.

\section{Data Analysis:}

Frequency distribution of demographic variables:

Table 1 : Demographic Details of Respondent

\begin{tabular}{|c|c|c|c|}
\hline & & Frequency & Percent \\
\hline \multirow{2}{*}{ Gender } & Male & 307 & 60.8 \\
\hline & Female & 198 & 39.2 \\
\hline \multirow{4}{*}{ Age } & Below 20 & 57 & 11.3 \\
\hline & $20-30$ & 338 & 66.9 \\
\hline & $30-40$ & 92 & 18.2 \\
\hline & Above 40 & 18 & 3.7 \\
\hline \multirow{4}{*}{ Education } & Intermediate \& diploma & 12 & 2.4 \\
\hline & Bachelor & 161 & 31.9 \\
\hline & Master & 299 & 59.2 \\
\hline & Doctrate & 33 & 6.5 \\
\hline \multirow{3}{*}{ Occupation } & Employed & 258 & 51.1 \\
\hline & Student (Not Working) & 241 & 47.7 \\
\hline & Home Maker & 6 & 1.2 \\
\hline \multirow{6}{*}{ Family Monthly Income } & Less than $₹ 10000$ & 70 & 13.9 \\
\hline & ₹ $10001-₹ 20000$ & 151 & 29.9 \\
\hline & ₹ $20001-₹ 30000$ & 105 & 20.8 \\
\hline & $₹ 30001-₹ 40000$ & 44 & 8.7 \\
\hline & 40001 - ₹ 50000 & 40 & 7.9 \\
\hline & Above $₹ 50000$ & 95 & 18.8 \\
\hline \multicolumn{2}{|c|}{ Total } & 505 & 100.0 \\
\hline
\end{tabular}

Table 1 was drawn to understand the demographic profile of the respondents and it was found that out of the total sample $(n=505) 60.8 \%$ consisted of male and $39.2 \%$ of female. Further we have divided the age group in four categories and we found that more than half $(66.9 \%)$ of respondents were in between the age group in between $20-30$ years, $18.2 \%$ were to the age group in between 30 to 40 year, $11.3 \%$ respondents were to the age group of below 20 years and $3.7 \%$ were to the age group of above 40 years.
We have categorized education level in five categories i.e. High school and below, intermediate and diploma, bachelor, master, doctorate. It was observed around $59.2 \%$ of respondents were having master's degree, $31.9 \%$ were bachelor's degree, $6.5 \%$ having doctorate, $2.4 \%$ were intermediate and diploma. We have categorized occupation in three categories i.e. employed, student (not employed), and home maker. It was observed $47.7 \%$ of respondents were students, $51.1 \%$ of respondents 
were employed, and $1.2 \%$ home maker. We have categorized family monthly income in six categories, It was observed around $29.9 \%$ of respondents were having income in between 10000 to $20000,20.8 \%$ of respondents were having income in between 20000 to $30000,8.7 \%$ of respondents were having income in between 30000 to $40000,7.9 \%$ of respondents were having income in between 40000 to $50000,18.8 \%$ were in income group of above 50000, and 13.9\% were in income group of less than 10000.

\section{Measures:}

\section{Reliability assessment:}

The Cronbach's Alpha test of reliability was applied to check the reliability of the questions based on the likert scale in the questionnaire (Cronbach, 1951). The alpha coefficient was checked for each factors identified after the exploratory factor analysis. The alpha value for each factor was in between .815 to .933 (see Table-2), the coefficient alpha should be greater than 0.7 , which shows that measurement is acceptable ( (Nunnally, 1978). All the questions used in the questionnaire were found reliable for the study.

Table 2 Reliability Statistics

\begin{tabular}{|l|c|c|}
\hline \multicolumn{1}{|c|}{ Identified Factors } & Alpha Value & No. of Items \\
\hline Performance Expectancy (PE) & .922 & 6 \\
\hline Effort Expectancy (EE) & .927 & 4 \\
\hline Self-Efficacy (SE) & .840 & 3 \\
\hline Social Influence (SI) & .861 & 3 \\
\hline Computer Anxiety (CA) & .876 & 4 \\
\hline Habit (HT) & .902 & 4 \\
\hline Hedonic Motivation (HM) & .923 & 3 \\
\hline Perceived Credibility (PC) & .925 & 6 \\
\hline Behavioral Intention (BI) & .929 & 3 \\
\hline Website Design (WD) & .933 & 6 \\
\hline Social Media (SM) & .896 & 5 \\
\hline Delivery of Goods (DOG) & .815 & 3 \\
\hline
\end{tabular}

\section{Exploratory Factor Analysis}

\section{Validity assessment:}

No cross loading has been found in the table of pattern Matrix, which shows that there exist discriminant validity. All the Average factor loadings for each factor have been found greater than .6, which shows that there exist convergent validity.

\section{KMO and Bartlett Test:}

The KMO and Bartlett Test of Sphericity was used for testing the adequacy of data and significance for applying exploratory factor analysis. The KMO value was found .965 (see Table-3) which should be greater than .6 and we found it greater than .9 which is marvelous (Kaiser \& Rice, 1974), which shows that sample size is adequate for the study. The Bartlett test of sphericity is also found significant (.000, less than .05) with degree of freedom 1225and chi-Square value 23845.056, indicates that the correlation matrix was not an identity matrix. The above facts show that the data collected on different factors affecting consumer's online shopping behavior from respondents were suitable for factor analysis. 
Table: 3 KMO and Bartlett's Test

\begin{tabular}{|l|l|r|}
\hline Kaiser-Meyer-Olkin Measure of Sampling Adequacy. & 0.965 \\
\hline Bartlett's Test of Sphericity & Approx. Chi-Square & 23845.056 \\
\cline { 2 - 3 } & df & 1225 \\
\cline { 2 - 3 } & Sig. & 0 \\
\hline
\end{tabular}

The raw scores of 50 items were subjected to Maximum Likelyhood method to identify the underlying factors that having impact on consumer's online shopping behaviour. The items having factor loading greater than .4 was considered as significant (Comrey \& Lee, 1992). After the analysis, it was found that there were twelve factors, with $78.939 \%$ of cumulative variance explained through the exploratory factor analysis. The communalities drived from were relatively large ranging from .526 to .884 confirmed that the data set is appropriate (Stewart, Feb., 1981). Following are the details of factors identified through EFA:

Table 4 : Pattern Matrix

\begin{tabular}{|c|c|c|c|c|c|c|c|c|c|c|c|c|c|c|c|c|}
\hline \multirow{2}{*}{ Items } & \multirow{2}{*}{$\begin{array}{l}\text { Factor } \\
\text { Name }\end{array}$} & \multicolumn{3}{|c|}{ Initial Eigenvalues } & \multicolumn{12}{|c|}{ Factor } \\
\hline & & \begin{tabular}{|l} 
Eigen \\
Value
\end{tabular} & $\begin{array}{l}\% \text { of } \\
\text { Variance }\end{array}$ & $\begin{array}{l}\text { Cumulati } \\
\text { ve \% }\end{array}$ & 1 & 2 & 3 & 4 & 5 & 6 & 7 & 8 & 9 & 10 & 11 & 12 \\
\hline WD7 & \multirow{6}{*}{$\begin{array}{l}\text { Website } \\
\text { Design }\end{array}$} & \multirow{6}{*}{25.393} & \multirow{6}{*}{50.785} & \multirow{6}{*}{50.785} & .987 & & & & & & & & & & & \\
\hline WD6 & & & & & .847 & & & & & & & & & & & \\
\hline WD3 & & & & & .843 & & & & & & & & & & & \\
\hline wD5 & & & & & .756 & & & & & & & & & & & \\
\hline WD4 & & & & & .741 & & & & & & & & & & & \\
\hline WD2 & & & & & .658 & & & & & & & & & & & \\
\hline PE2 & \multirow{6}{*}{$\begin{array}{c}\text { Performan } \\
\text { ce } \\
\text { Expectanc } \\
y\end{array}$} & \multirow{6}{*}{2.813} & \multirow{6}{*}{5.627} & \multirow{6}{*}{56.412} & & 1.045 & & & & & & & & & & \\
\hline PE 3 & & & & & & .891 & & & & & & & & & & \\
\hline PE1 & & & & & & .796 & & & & & & & & & & \\
\hline PE4 & & & & & & .791 & & & & & & & & & & \\
\hline PES & & & & & & .511 & & & & & & & & & & \\
\hline PE 5 & & & & & & .480 & & & & & & & & & & \\
\hline HT2 & \multirow{4}{*}{ Habit } & \multirow{4}{*}{1.818} & \multirow{4}{*}{3.636} & \multirow{4}{*}{60.048} & & & 1.086 & & & & & & & & & \\
\hline HT 4 & & & & & & & .682 & & & & & & & & & \\
\hline HT1 & & & & & & & .654 & & & & & & & & & \\
\hline HT3 & & & & & & & .647 & & & & & & & & & \\
\hline$\overline{S M 5}$ & \multirow{5}{*}{$\begin{array}{l}\text { Social } \\
\text { Media }\end{array}$} & \multirow{5}{*}{1.744} & \multirow{5}{*}{3.489} & \multirow{5}{*}{63.537} & & & & .758 & & & & & & & & \\
\hline SM2 & & & & & & & & .751 & & & & & & & & \\
\hline SM3 & & & & & & & & .723 & & & & & & & & \\
\hline SM6 & & & & & & & & .665 & & & & & & & & \\
\hline SM4 & & & & & & & & .560 & & & & & & & & \\
\hline $\mathrm{EE} 2$ & \multirow{4}{*}{$\begin{array}{c}\text { Effort } \\
\text { Expectanc } \\
y\end{array}$} & \multirow{4}{*}{1.384} & \multirow{4}{*}{2.768} & & & & & & .941 & & & & & & & \\
\hline EE1 & & & & 66305 & & & & & .938 & & & & & & & \\
\hline EE3 & & & & 00.505 & & & & & .762 & & & & & & & \\
\hline $\mathrm{EE} 4$ & & & & & & & & & .617 & & & & & & & \\
\hline PC5 & & & & & & & & & & .891 & & & & & & \\
\hline $\mathrm{PC4}$ & & & & & & & & & & .742 & & & & & & \\
\hline PC3 & Percieved & 134 & 2267 & 68572 & & & & & & .710 & & & & & & \\
\hline $\mathrm{PC} 2$ & Credability & 1.134 & 2.267 & $68.3 / 2$ & & & & & & .696 & & & & & & \\
\hline $\mathrm{PCl}$ & & & & & & & & & & .676 & & & & & & \\
\hline PC6 & & & & & & & & & & .523 & & & & & & \\
\hline DOG2 & & & & & & & & & & & .929 & & & & & \\
\hline DOG1 & Delivery of & 1.058 & 2.116 & 70.689 & & & & & & & .700 & & & & & \\
\hline DOG3 & & & & & & & & & & & .485 & & & & & \\
\hline
\end{tabular}




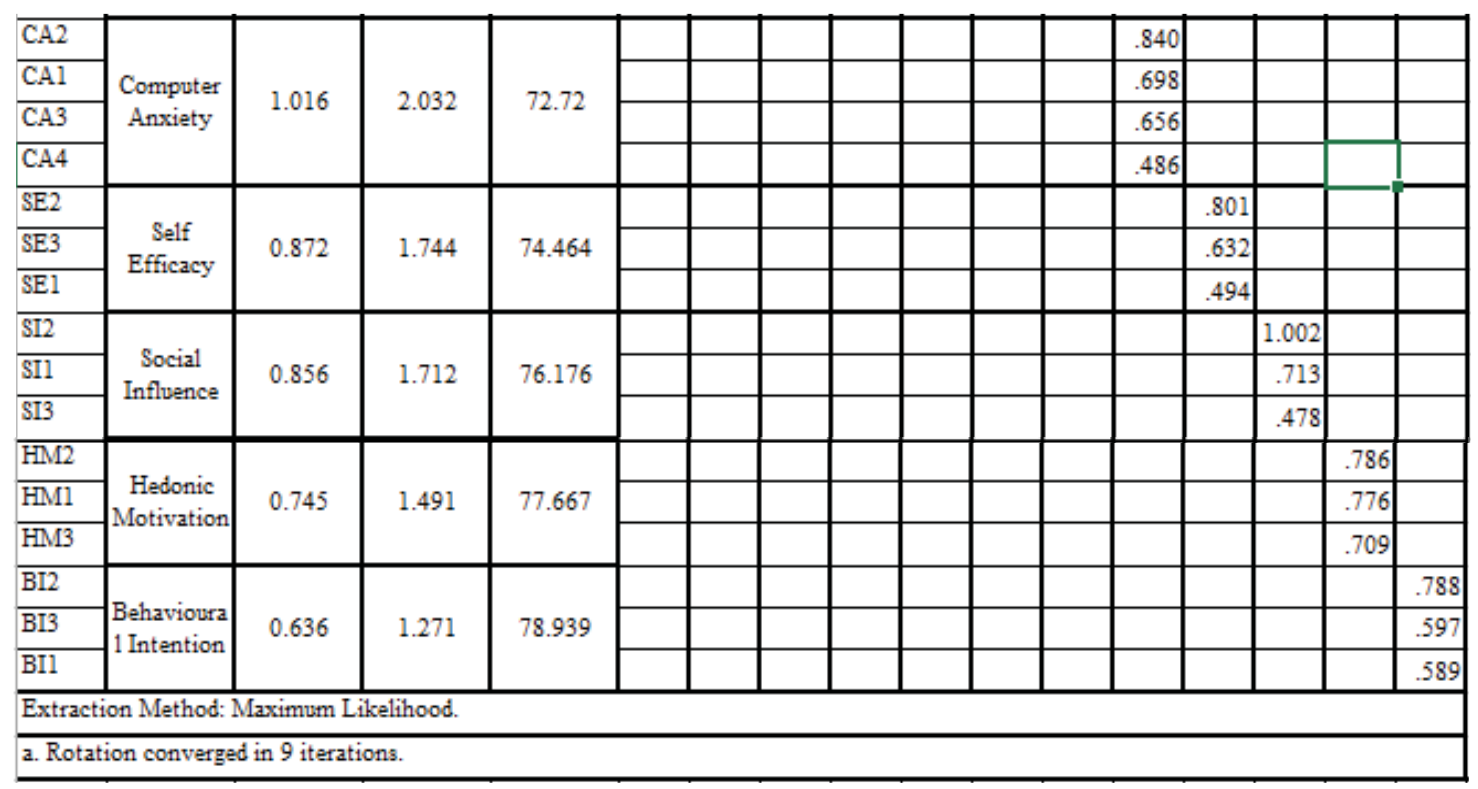

\section{Goodness-of-fit Test:}

Goodness-of-fit Test is found significant with the P value .000 . It shows that best no. of factors have been extracted from the data used in this study.

Table 5 : Goodness- of-fit Test

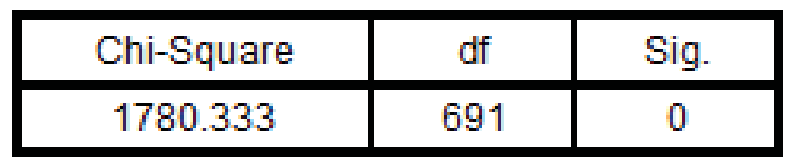

\section{Multiple Regression Analysis:}

Multiple regression analysis was applied including eleven independent variables (Website design, performance expectancy, habit, social media, effort expectancy, perceived credibility, delivery of goods, computer anxiety, self-efficacy, social influence, hedonic motivation) and one dependent variable (Behavioural Intention) to develop a regression model. In this multiple regression analysis stepwise method was applied. Table 6, shows that the value of $R$ square is .707, which means that the regression model is representing $70 \%$ of the variance in the dependent variable by the independent variables. As $F(1,498)=5.552$, p value is .019 which is less than 0.05 , advocate that the model is significant.

Table 6 : Model summary ${ }^{\mathrm{f}}$

\begin{tabular}{|c|c|c|c|c|c|c|c|c|c|}
\hline \multirow[b]{2}{*}{$\mathrm{R}$} & \multirow[b]{2}{*}{ R Square } & \multirow{2}{*}{$\begin{array}{l}\text { Adjusted } \\
\text { R Square }\end{array}$} & \multirow{2}{*}{$\begin{array}{l}\text { Std. Error } \\
\text { of the } \\
\text { Estimate }\end{array}$} & \multicolumn{5}{|c|}{ Change Statistics } & \multirow{2}{*}{$\begin{array}{l}\text { Durbin- } \\
\text { Watson }\end{array}$} \\
\hline & & & & $\begin{array}{c}\text { R Square } \\
\text { Change }\end{array}$ & F Change & df1 & $\mathrm{df} 2$ & $\begin{array}{c}\text { Sig. F } \\
\text { Change }\end{array}$ & \\
\hline $.841^{\mathrm{e}}$ & 0.707 & 0.704 & 0.519909 & 0.003 & 5.552 & 1 & 498 & 0.019 & 1.832 \\
\hline
\end{tabular}

f. Predictors: (Constant), WD, HT, PE, SE, EE, SM

g. Dependent Variable: BI 
The Table 7 is representing the result of ANOVA, which shows that the value of $F(6,498)$ is 200.642 with $p$ value .000 which is less than 0.05 , tells that it is significant and the regression model is deemed to predict consumer's online shopping behavioural intention.

Table 7 : ANOVA ${ }^{a}$

\begin{tabular}{|l|r|r|c|c|c}
\hline & $\begin{array}{c}\text { Sum of } \\
\text { Squares }\end{array}$ & df & $\begin{array}{c}\text { Mean } \\
\text { Square }\end{array}$ & F & Sig. \\
\hline Regression & 325.407 & 6 & 554.235 & \multirow{2}{*}{200.642} & \multirow{2}{*}{$.000^{9}$} \\
\hline Residual & 134.612 & 498 & 0.27 & & \\
\hline Total & 460.019 & 504 & & & \\
\hline
\end{tabular}

a. Dependent Variable: $\mathrm{BI}$

f. Predictors: (Constant), WD, HT, PE, PC, EE

In the table 8 , it is shown that website design, habit, performance expectancy perceived credibility and effort expectancy is having a significant $(\mathrm{p}<0.05)$ impact on consumer's online shopping behavioural intention. So the null hypothesis $\mathrm{HOa}, \mathrm{HOb}, \mathrm{HOc}, \mathrm{HOe}, \mathrm{HOd}$ and $\mathrm{HOi}$ is rejected.

Table 8 : Coefficients ${ }^{\mathrm{a}}$

\begin{tabular}{|c|c|c|c|c|c|c|c|c|}
\hline \multirow{2}{*}{ Model } & \multicolumn{2}{|c|}{$\begin{array}{l}\text { Unstandardized } \\
\text { Coefficients }\end{array}$} & \multirow{2}{*}{\begin{tabular}{|c}
$\begin{array}{c}\text { Standardiz } \\
\text { ed } \\
\text { Coefficient } \\
\text { s }\end{array}$ \\
Beta
\end{tabular}} & \multirow{2}{*}{$\mathrm{t}$} & \multirow{2}{*}{ Sig. } & \multicolumn{3}{|c|}{ Correlations } \\
\hline & $\mathrm{B}$ & Std. Error & & & & Zero-order & Partial & Part \\
\hline (Constant) & $5.51 \mathrm{E}-17$ & 0.023136 & & $2.383 \mathrm{E}-15$ & 1 & & & \\
\hline WD & 0.408823 & 0.041421 & 0.417378 & 9.8698162 & $4.19 \mathrm{E}-21$ & 0.744546 & 0.404483 & 0.239248 \\
\hline HT & 0.375717 & 0.032248 & 0.381878 & 11.650892 & $6.58 \mathrm{E}-28$ & 0.679943 & 0.46281 & 0.282422 \\
\hline $\mathrm{PE}$ & 0.218 & 0.044535 & 0.222843 & 4.8949824 & 1.33E-06 & 0.708392 & 0.214256 & 0.118656 \\
\hline SE & -0.14436 & 0.035863 & -0.13921 & -4.0253428 & $6.575 \mathrm{E}-05$ & 0.47479 & -0.17752 & -0.09758 \\
\hline EE & 0.134016 & 0.043912 & 0.136687 & 3.0518967 & 0.0023954 & 0.662064 & 0.135498 & 0.073979 \\
\hline SM & -0.08402 & 0.035659 & -0.0839 & -2.3562481 & 0.0188471 & 0.539901 & -0.105 & -0.05712 \\
\hline
\end{tabular}

Table 9 is representing the excluded variables from the regression model, which means social influence, computer anxiety, hedonic motivation, social media, delivery of goods, self-efficacy is not having a significant ( $p>0.05)$ impact on consumer's online shopping behavioural intention. So the null hypothesis H0g, H0h, H0f, $\mathrm{HOj}$, and HOk is fail to reject.

Table 9 : Excluded Variables ${ }^{a}$

\begin{tabular}{|c|c|c|c|c|c|}
\hline & \multirow{2}{*}{ Beta In } & $\mathrm{t}$ & Sig. & \multirow{2}{*}{$\begin{array}{c}\text { Partial } \\
\text { Correlation }\end{array}$} & $\begin{array}{c}\text { Collinearity } \\
\text { Statistics }\end{array}$ \\
\cline { 6 - 7 } & & & & & Tolerance \\
\hline PC & $.000 \mathrm{~g}$ & -0.00526 & 0.995806 & -0.0002359 & 0.2825602 \\
\hline DOG & $.001 \mathrm{~g}$ & 0.025844 & 0.979392 & 0.0011593 & 0.4637448 \\
\hline CA & $-.036 \mathrm{~g}$ & -0.85768 & 0.391485 & -0.0384436 & 0.3302608 \\
\hline SI & $-.007 \mathrm{~g}$ & -0.18092 & 0.856502 & -0.0081152 & 0.3438253 \\
\hline HM & $-.009 \mathrm{~g}$ & -0.20646 & 0.836518 & -0.0092605 & 0.3008829 \\
\hline
\end{tabular}

a. Dependent Variable: BI

g. Predictors in the Model: (Constant), WD, HT, PE, SE, EE, SM 


\section{The Regression Model:}

On the basis of the result of the multiple regression analysis using stepwise method, the proposed model is as below:

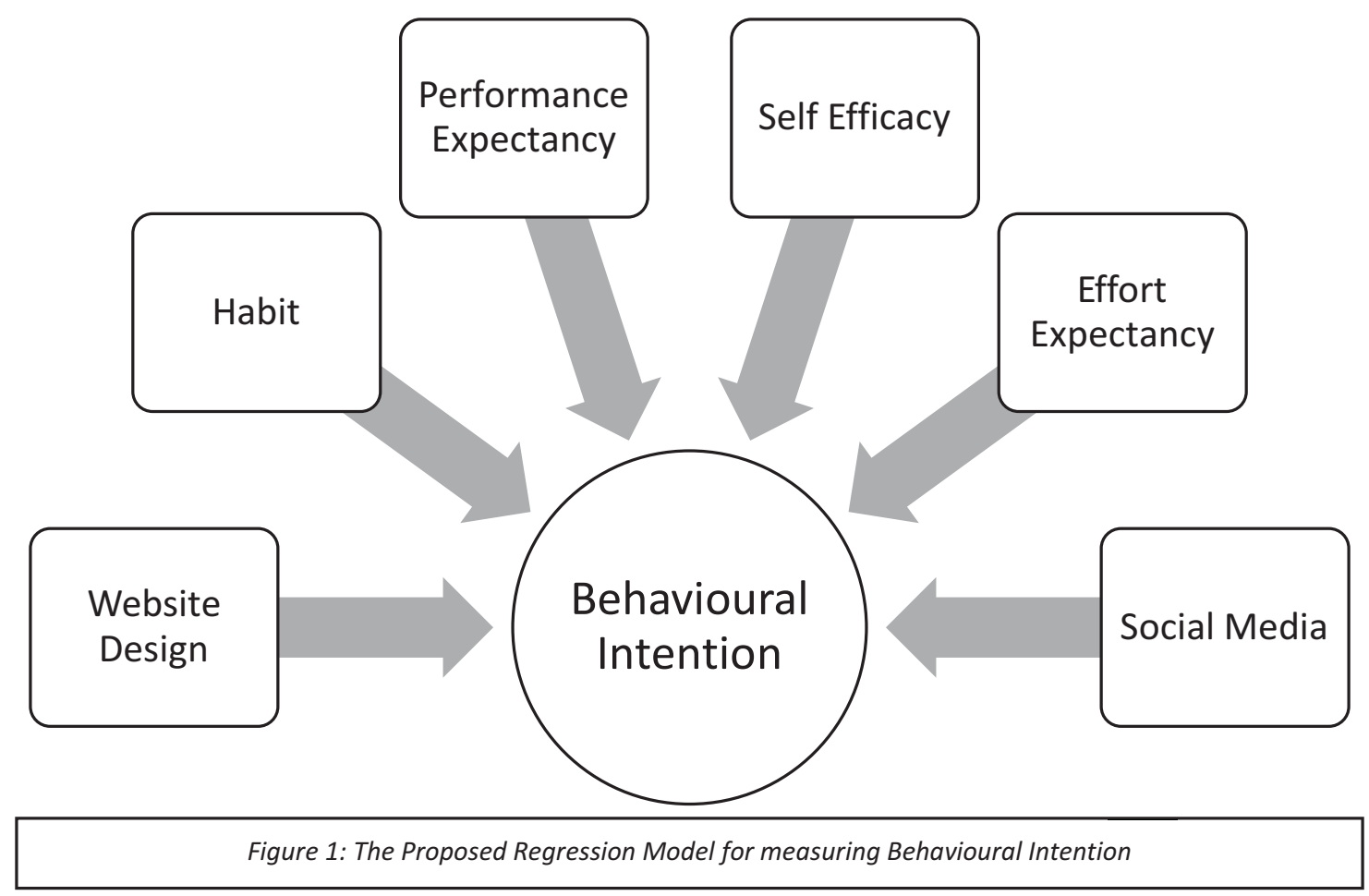

Regression Line: $\mathrm{BI}=5.51+.408 \mathrm{WD}+.375 \mathrm{HT}+.218 \mathrm{PE}-.144 \mathrm{SE}+.134 \mathrm{EE}-.084 \mathrm{SM}$

It represents that the consumer's online shopping behavioural intention is having significant impact on website design, habit, performance expectancy perceived credibility and effort expectancy. With the help of regression line $\mathrm{BI}=5.51+.408 \mathrm{WD}+.375 \mathrm{HT}$ $+.218 \mathrm{PE}-.144 \mathrm{SE}+.134 \mathrm{EE}-.084 \mathrm{SM}$, the behavioural intention can be predicted.

\section{Discussion and conclusions:}

In this study we found that there are twelve factors that affect consumer's online shopping buying behaviour. These factors are social influence, selfefficacy, perceived credibility, performance expectancy, effort expectancy, habit, hedonic motivation, computer anxiety, website design, social media, delivery of goods and behavioural intention. Out of these factors website design is having a positive impact on consumer's intention to by online, the same result was also found by (Zhou, Lu, \& Wang, 2009), consumer's habit influence a consumer to purchase products online repeatedly, online shopping experience and online shopping habit is having a similar effect on behavioural intention to purchase online (Khalifa \& Liu, 2007), performance expectancy plays an important role while consumer makes purchase decision to buy online, it affects hedonic and utilitarian performance expectancy (Yang, 2010). Self-efficacy is having a significant effect on purchase intention, privacy protection, data integrity and nonrepudiation are main reason behind it (Suh \& Han, 2003), Effort expectancy also is having a significant impact on consumer's online shopping behavioural intention (Venkatesh, Thong, \& Xu, March 2012) and social media is also having the significant impact on consumers buying behaviour. Social influence, computer anxiety, hedonic motivation, perceived credibility, delivery 
of goods, is not having a significant impact on consumer's online shopping behavioral intention. Online shopping has been becoming a habit for the consumers. They are addicted to do online shopping and becoming natural to them. The consumers feel that online shopping is useful in their daily life. It enables them to accomplish the shopping more quickly which increases the effective use of time. They also feel that online shopping provides better choices and quality product with discounts incentive schemes and reasonable prices. The consumers feel that it is easy to learn and use online shopping. They trust the online shopping system, feel safe and secure and do not feel risky when conduct online transaction through debit cards, credit cards, and net banking.

\section{Limitation and future research}

A limitation of this study lies with the sample size. Sample size 505 is small in comparison to no. of online shopping users in India. The results of the study can be generalized to central U.P. not to pan India. Further in future the impact of moderators in the proposed regression model can be assessed. The result of EFA is explaining $78.93 \%$ variance in the study with twelve factors, In future there can be other factors explaining the additional variance in the model.

\section{Implications}

The findings of this research can be implemented by the E-retailers in decision making while creating the marketing program. The study suggest that the Eretailers should create an attractive website design which display discounts and schemes on the home page of the website with easy search options. It should also provide the product rating, vendor rating, customer review, and 3D images of the products with zoom facility, easy options to compare the product and few steps to complete the final purchase. The E-retailers should try to provide better services to the consumers as it will lead to satisfaction and satisfaction level affect the consumer's habit to purchase online. Consumers feel that online shopping is useful in their daily life, and this shows that there is a scope in online retailing of the product.

\section{REFERENCES}

1) Alnsour, M., Ismael, N., Nsoor, Z., \& Feidi, M. (2019). The Perceived Risks Affecting Online Shopping Adoption in Jordan. International Journal of Online Marketing, Volume $9 \bullet$ Issue 2, pg. 1-12.

2) Bai, B., Law, R., \& Wen, I. (2008). The impact of website quality on customer satisfaction and purchase. International Journal of Hospitality Management, 27, 391-402.

3) Bianchi, C., \& Andrews, L. (2012). Risk, trust, and consumer online purchasing behaviour: a Chilean perspective. International Marketing Review, Vol. 29 Iss 3 pp. 253 - 275.

4) Cao, Y., Ajjan, H., \& Hong, P. (2018). Postpurchase shipping and customer service experiences in online shopping and their impact on customer satisfaction: An empirical study with comparison . Asia Pacific Journal of Marketing and Logistics, Vol. 30 Issue: 2, pp.400416.

5) Changchit, C., Cutshall, R., Lonkani, R., Pholwan, K., \& Pongwiritthon, R. (2018). Determinants of Online Shopping Influencing Thai Consumer's Buying Choices. Journal of Internet Commerce, pg. 1-23.

6) Comrey, A. L., \& Lee, H. B. (1992). A first course in factor analysis (2nd ed.). Hillsdale, NJ, US: Lawrence Erlbaum Associates, Inc.

7) Cronbach, L. J. (1951). Coefficient Alpha and the Internal Structures. Psychometrika, 16(3), 297333.

8) Gauri, D. K., Bhatnagar, A., \& Rao, R. (2008). Role of Word of Mouth in Online Store Loyalty. COMMUNICATIONS OF THE ACM, Vol. 51, No. 3, pp. 89 - 91.

9) Gupta, A., \& Arora, N. (2017). Understanding determinants and barriers of mobile shopping adoption using behavioral reasoning theory. 
Journal of Retailing and Consumer Services, 1-7.

10) Hassanein, K., \& Head, M. (2007). Manipulating perceived social presence through the web interface and its impact on attitude towards online shopping. Int. J. Human-Computer Studies, 65, 689-708.

11) Hausman, A. V., \& Siekpe, J. S. (2009). The effect of web interface features on consumer online purchase intentions. Journal of Business Research, 62, 5-13.

12) Hernandez, B., Jimenez, J., \& Martin, M. J. (2009). The impact of self-efficacy, ease of use and usefulness on e-purchasing: An analysis of experienced e-shoppers. Interacting with Computers, 21, 146-156.

13) Hill, W. W., \& Beatty, S. E. (2011). A model of adolescents' online consumer self-efficacy (OCSE). Journal of Business Research, 64, 1025-1033.

14) IBEF. (2019, March). E-commerce Industry in India. Retrieved from www.ibef.org: www.ibef.org/industry/ecommerce.aspx

15) Izogo, E. E., \& Jayawardhena, C. (2018). Online shopping experience in an emerging e-retailing market. Journal of Research in Interactive Marketing, https://doi.org/10.1108/JRIM-022017-0015.

16) Kaiser, H. F., \& Rice, J. (1974). Little Jiffy Mark IV. Educational and Psychological Measurement, 34(1), 111-17.

17) Khalifa, M., \& Liu, V. (2007). Online consumer retention: contingent effects of online shopping habit and online shopping experience. European Journal of Information Systems, 6:6, 780-792.

18) Kim, S. Y., \& Lim, Y. J. (2010). Consumers' Perceived Importance of and Satisfaction with Internet Shopping. Electronic Markets, 11:3, 148154.

19) Lu, H. P., Hsu, C. L., \& Hsu, Y. H. (2005). An empirical study of the effect of perceived risk upon intention to use online applications. Information Management \& Computer Security, Vol. 13 Iss 2 pp. $106-120$.

20) Nunnally, J. C. (1978). Psychometric Theory: 2nd Ed. New York: McGraw-Hill.
21) Park, H., \& Cho, H. (2012). Social network online communities: information sources for apparel shopping. Journal of Consumer Marketing, Vol. 29 Iss 6 pp. 400 - 411.

22) Pengnate, S., \& Sarathy, R. (2017). An experimental investigation of the influence of website emotional design features on trust in unfamiliar online vendors. Computers in Human Behavior, 49-60.

23) Pookulangara, S., \& Koesler, K. (2011). Cultural influence on consumers' usage of social networks. Journal of Retailing and Consumer Services, 18, 348-354.

24) Singh, J. P., Irani, S., Rana, N. P., Dwivedi, Y. K., Saumya, S., \& Roy, P. K. (2016). Predicting the "helpfulness" of online consumer reviews. Journal of Business Research, 346-355.

25) Singh, N., Fassorr, G., Chao, M. C., \& Hoffmann, J. A. (2006). Understanding international web site usage: A cross-national study of German, Brazilian,and Taiwanese online consumers. International Marketing Review, Vol. 23 Iss 1 pp. 83 - 97.

26) Stewart, D. W. (Feb., 1981). The Application and Misapplication of Factor Analysis in Marketing Research. Journal of Marketing Research, Vol. 18, No. 1, pp. 51-62.

27) Suh, B., \& Han, I. (2003). The Impact of Customer Trust and Perception of Security Control on the Acceptance of Eletronic Commerce. International Journal of Electronic Commerce, Vol. 7, No. 3, pp. 135-161.

28) Tandon, U., Kiran, R., \& Sah, A. N. (2017). Understanding barriers and drivers to online shopping: an emerging economy case. International Journal of Electronic Business, Vol. 13, Nos. 2/3, pg. 216-243.

29) Tarhini, A., Alalwan, A. A., Al-Qirim, N., Algharabat, R., \& Masa'deh,, R. (2018). An Analysis of the Factors Influencing the Adoption of Online Shopping. International Journal of Technology Diffusion, Volume 9 - Issue 3, pg. 68-87.

30) Venkatesh, V., Thong, J. Y., \& Xu, X. (March 2012). Consumer Acceptance and Use of 
Information Technology: Extending the Unified Theoryof Acceptance and Use of Technology. MIS Quarterly, Vol. 36, No. 1, pp. 157-178.

31) Wang, X., Yu, C., \& Wei, Y. (2012). Social Media Peer Communication and Impacts on Purchase Intentions: A Consumer Socialization Framework. Journal of Interactive Marketing, 26, 198-208.

32) Yang, K. (2010). Determinants of US consumer mobile shopping services adoption: implications for designing mobile shopping services. Journal of Consumer Marketing, Vol. 27 Issue: 3, pp.262270.

33) Zhou, T., Lu, Y., \& Wang, B. (2009). The Relative Importance of Website Design Quality and Service Quality in Determining Consumers' Online Repurchase Behavior. Information Systems Management, 26: 327-337. 